\title{
Glyphosate-Residues in Roundup-Ready Soybean Impair Daphnia magna Life-Cycle
}

\author{
Marek Cuhra1 $^{1 *}$, Terje Traavik ${ }^{1,2}$, Mickaël Dando',2, Raul Primicerio3, \\ Daniel Ferreira Holderbaum ${ }^{4}$, Thomas Bøhn ${ }^{1,2}$ \\ ${ }^{1}$ Faculty of Health Sciences, The Arctic University of Norway, Troms $\varnothing$, Norway \\ ${ }^{2} \mathrm{Gen} \emptyset \mathrm{k}$-Centre for Biosafety, The Science Park, Troms $\varnothing$, Norway \\ ${ }^{3}$ Faculty of Biosciences, Fisheries and Economics, The Arctic University of Norway, Troms $\varnothing$, Norway \\ ${ }^{4}$ Graduate Program in Plant Genetic Resources, Federal University of Santa Catarina (UFSC), Florianópolis, Brazil \\ Email: ${ }^{*}$ marek.cuhra@gmail.com
}

Received 5 January 2015; accepted 24 January 2015; published 30 January 2015

Copyright (C) 2015 by authors and Scientific Research Publishing Inc.

This work is licensed under the Creative Commons Attribution International License (CC BY).

http://creativecommons.org/licenses/by/4.0/

(c) (i) Open Access

\begin{abstract}
Herbicide tolerant plants such as Roundup-Ready soybean contain residues of glyphosate herbicide. These residues are considered safe and previous animal-feeding-studies have failed to find negative effects related to such chemical residues. The present study tests 8 experimental soymeal diets as feed in groups (each containing 20 individuals) of test-animals (D. magna). The diets have different levels of glyphosate residues and we show that animal growth, reproductive maturity and number of offspring are correlated with these chemicals. The tested soybeans are from ordinary agriculture in Iowa USA and the residues are below the regulatory limits. Despite this, clear negative effects are seen in life-long feeding. The work enhances the need for including analysis of herbicide residues in future assessment of GMO.
\end{abstract}

\section{Keywords}

Transgenic GTS 40-3-2 Roundup-Ready Soybean, Glyphosate Residues, Life-Long Animal Feeding Study, GMO Risk-Assessment, Herbicide-Tolerant Cultivar Quality, Aquatic Invertebrate Ecotoxicology

\section{Introduction}

Transgenic glyphosate-tolerant soy (Roundup-Ready soybean = RR-soybean) is the most commonly cultivated genetically modified crop, contributing approximately $80 \%$ of global annual soy production of 283 million metric

\footnotetext{
${ }^{*}$ Corresponding author.
}

How to cite this paper: Cuhra, M., Traavik, T., Dando, M., Primicerio, R., Holderbaum, D.F. and Bøhn, T. (2015) GlyphosateResidues in Roundup-Ready Soybean Impair Daphnia magna Life-Cycle. Journal of Agricultural Chemistry and Environment, 4, 24-36. http://dx.doi.org/10.4236/jacen.2015.41003 
tons in the 2013/14 growing season [1]. Previous studies found compositional differences between organic, conventional and RR-soybean and demonstrated that these differences were correlated with cultivating regime, notably the use of pesticides and resulting residue levels in plant material [2]. Subsequent feeding studies with the same soy materials demonstrated that $D$. magna vital parameters survival, growth and fecundity were significantly affected by soy type, with animals fed diets made from genetically modified soybean demonstrating significantly reduced fitness. The observed differences were attributed to differences in soybean composition, notably content of glyphosate residues [3]. Ecotoxicological testing of Roundup herbicide and its glyphosate active ingredient indicated that $D$. magna sensitivity to these toxins is considerably higher than previously reported. Cuhra et al. [4] found that concentrations of 1.35 - $4.05 \mathrm{mg} / \mathrm{l}$ of glyphosate or Roundup herbicide in aqueous medium, negatively affected survival, and $0.05-0.45 \mathrm{mg} / \mathrm{l}$ reduced growth, reproduction and offspring birth size.

Through their systemic mode of action, glyphosate-herbicides such as Roundup enter plant tissue and affect vegetative parts of plants by interfering with important metabolic pathways [5]. Transgenic crops such as GTS40-3-2 RR-soybean have been modified to have alternative and non-susceptible metabolic pathways and thus to withstand the toxic action. However, such modified plants are found to accumulate glyphosate residues from applied glyphosate-herbicide formulations [2] [6]. In this study we define "glyphosate residues" as the sum of glyphosate and its main degradation product aminomethyl-phosphonic acid (AMPA).

Regrettably, information concerning glyphosate-herbicide residues in soybean is sparse [6] [7], but recent studies have disclosed surprisingly high levels of glyphosate residues in RR-soybean (Figure 1), even in excess of regulatory guidelines limits [8]. Furthermore, it was found that the presence of glyphosate residues was significantly correlated with distinct differences in nutritional components of soybean, indicating a possible influence of such residues on soy nutritional constituents [2]. Glyphosate residues in glyphosate-tolerant cultivars are found to impact plant metabolism affecting grain composition [9]-[11].

Globally, protein-meal and oil from soybean (Glycine max) have become important ingredients in feed formulations for domestic mammals and are increasingly used as an affordable substitute for exhausted and costly traditional ingredients such as marine proteins and lipids for formulated feeds in aquaculture farming of fish such as Atlantic salmon Salmo salar [12] [13], rainbow trout Oncorhynchus mykiss [14] [15], and in aquaculture of crustaceans, such as crayfish [16] [17], prawn and shrimp [18].

Accordingly, the consequences of glyphosate accumulation in RR-soybean and the influence of such residues on in-plantae metabolic processes and soybean quality should be further investigated. In the present study we fed 8 defined experimental diets to $D$. magna in order to reveal possible impacts of soybean glyphosate. The diets were produced from individual harvests of RR-soy, representing a range of glyphosate residues, from 1.1 $\mathrm{mg} / \mathrm{kg}$ up to $15.1 \mathrm{mg} / \mathrm{kg}$ in the highest concentration, well below current USA maximum-residue-limits (MRLs) of $40 \mathrm{mg} / \mathrm{kg}$.

\section{Experimental Hypothesis}

$\mathrm{H}_{0}$ : Soybean-meal diets with varying content of glyphosate residues will not induce differences in measurable end-points for life-cycle traits survival, growth and reproduction in D. magna life-long feeding studies.

\section{Results}

\subsection{Survival}

Three out of the four groups of D. magna with the highest mortality were the groups fed soy with the highest glyphosate residues (Figure 1). And the group with lowest mortality (exempting the control group) was the group fed soy with the lowest residue level of glyphosate (Figure 2). However, there was not a full consistency in the results to support a simple dose-response relationship between glyphosate residues and mortality. Mortality was significantly higher in the groups fed soy with high glyphosate $(13.6-15.1 \mathrm{mg} / \mathrm{kg})$ residues as compared to medium (9.1 - $10.7 \mathrm{mg} / \mathrm{kg}$ ) or low ( 1.1 and $2.5 \mathrm{mg} / \mathrm{kg}$ ) levels ( $p=0.0066$ and 0.0068 respectively, Cox-PH test). No difference was found between animals fed soy that contained low and medium levels of glyphosate $(p=0.75)$.

\subsection{Growth}

Measurement of carapace length of D. magna at days 12, 21, 30 and 42 showed that growth was negatively affected by levels of glyphosate residues at the ages of 21 and 30 days $\left(p=0.02, \mathrm{R}^{2}=4.5 \%\right.$ and $p=0.031, \mathrm{R}^{2}=$ 


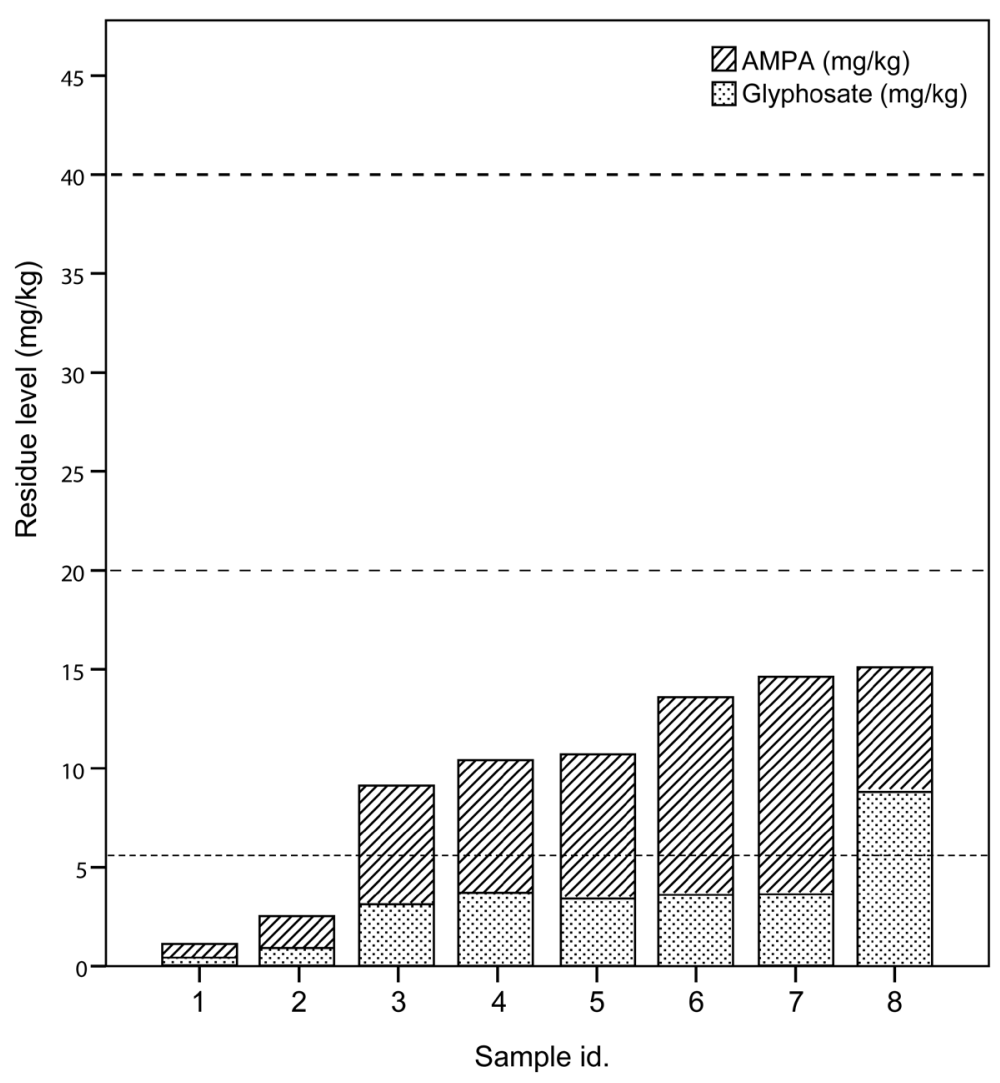

Figure 1. Soy glyphosate and AMPA levels $(\mathrm{mg} / \mathrm{kg})$ in relation to relevant regulatory limit (MRL). Data from [2].

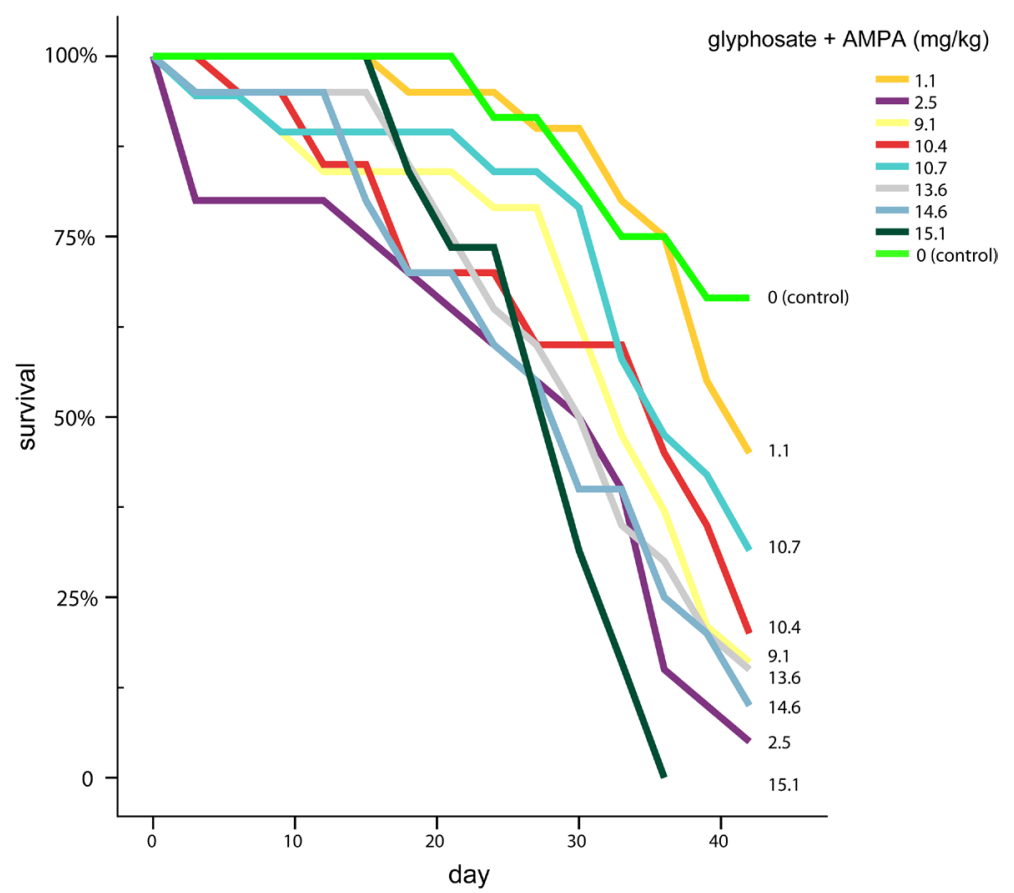

Figure 2. D. magna survival rates in relation to levels of glyphosate/AMPA residues. 
5.3\%, respectively) (Figure 3). At ages 12 and 42 days no significant correlation was found between body size and residue content of the diet. By day 42, the few surviving animals displayed a high variation in body size, visibly influencing the width of the confidence bands.

\subsection{Reproduction}

Age at maturity increased with the glyphosate residues in the soy feed $\left(p=0.005, \mathrm{R}^{2}=5.3 \%\right)$ (Figure 4). Cumulative fecundity of $D$. magna was significantly, negatively correlated with the herbicide residue level at the ages of 6 days and 9 days $\left(p=0.006, \mathrm{R}^{2}=4.2 \%\right.$, and $p=0.019, \mathrm{R}^{2}=2.0 \%$, Pearson-correlation, respectively). However, analyses of data on fecundity at ages $12,15,18,21,27,30,33$ and 36 days showed that the negative effect on fecundity disappeared over time. At the age of 42 days there was a significant positive correlation ( $p=$ $0.019, \mathrm{R}^{2}=17.5 \%$ ), based on small sample sizes due to high mortality (Figure 5). Analysis of abortion rates (Figure S1) showed no correlation with feed glyphosate residue content $(p=0.407)$. The total cumulated fecundity for the whole life-span (Figure S2) was negatively correlated with the level of glyphosate residues in feed ( $p=0.024, \mathrm{R}^{2}=3.4 \%$, Pearson correlation).
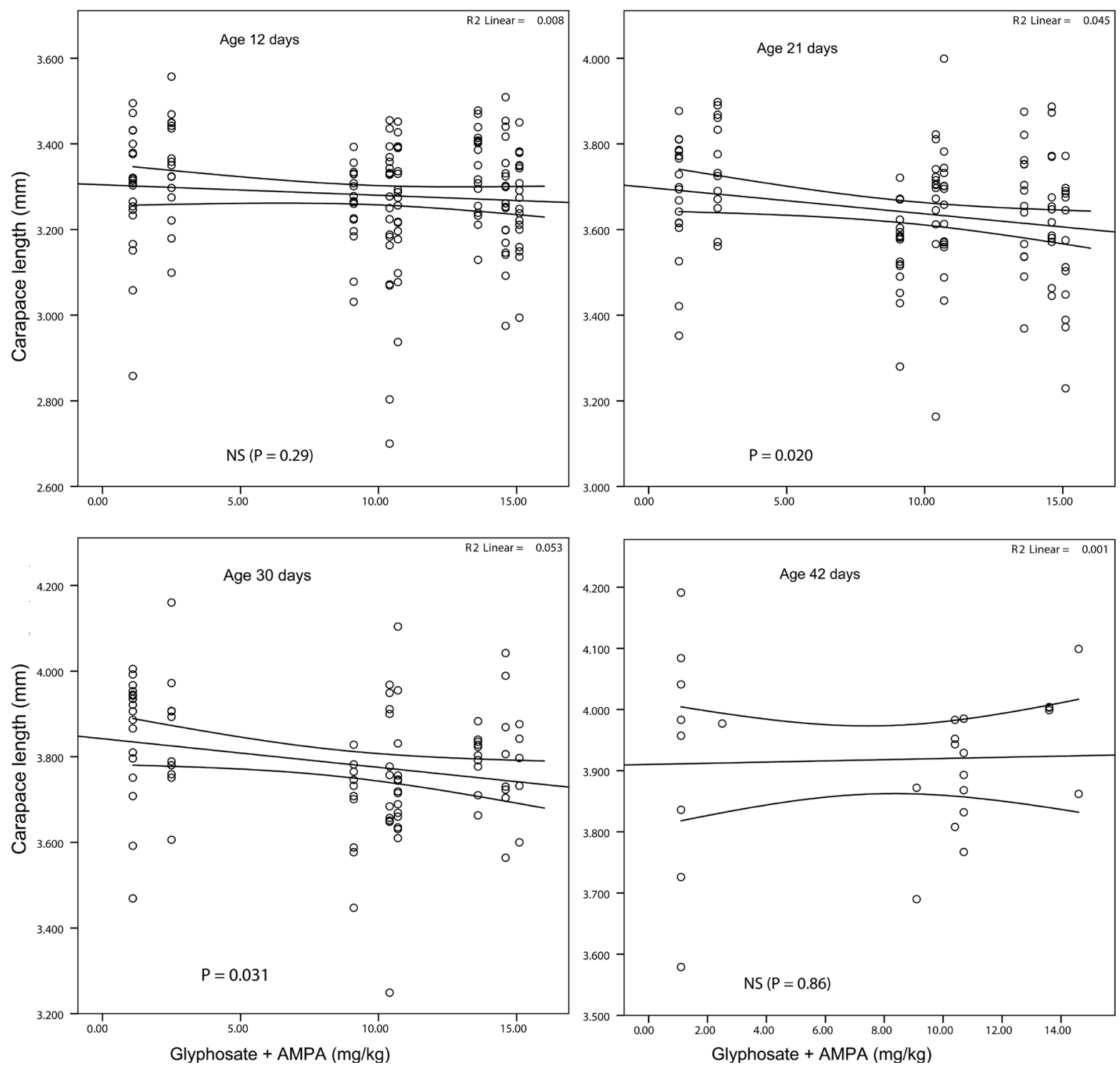

Figure 3. Body length (length of carapace) measured at age 12, 21, 30 and 42 days for D. magna fed experimental diets with varying levels of glyphosate residues (Error-bands: 95\% CI). 


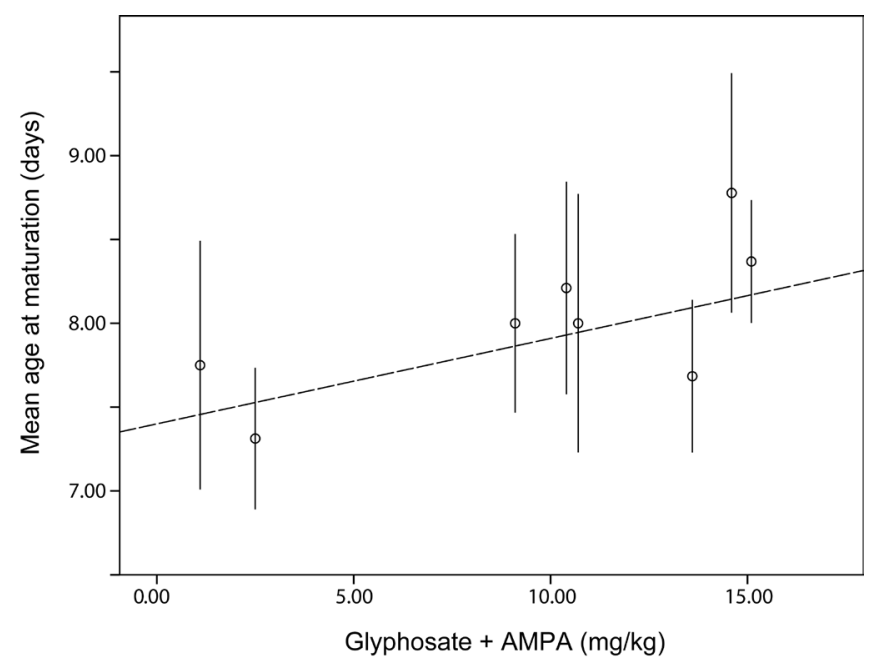

Figure 4. Mean age at maturation (time of first live birth) of $D$. magna fed experimental diets with varying levels of glyphosate residues (Error bars: 95\% CI).

\section{Discussion}

The life-cycle feeding studies with Roundup-Ready soybean (RR-soybean) in D. magna demonstrated several interesting findings: high levels of glyphosate residues in the soybean feed tested correlated with 1) higher mortality, 2) reduced growth and fecundity in some parts of the life-cycle, 3) delayed reproduction, and a reduced total number of offspring. None of the statistical associations were particularly strong with $\mathrm{R}^{2}$ (variation explained) typically below 5\% - 6\%. However, the consistent and significantly negative effect of glyphosate on a range of life-history traits can arguably be used as a proof of concept that glyphosate residues in Roundup Ready soybean have adverse biological effects at "normally occurring levels" (i.e. as found in "ready to market" soybeans) in the investigated dominant feed-ingredient. These results accentuate the demand for further studies on potential effects of herbicide residues present in genetically modified herbicide tolerant crops such as RR-soybean. Whether the observed negative impacts are due to, e.g., low-grade toxicity, endocrine disruption or antinutritional effects, can only be clarified by further well-designed feeding experiments.

Importantly, life-cycle ecotoxicology testing of Roundup herbicide and glyphosate in living-environment of $D$. magna [4] has demonstrated reduced survival, growth and fecundity attributable to low environmental levels of these chemicals. It is thus not unreasonable to relate the effects we see in animals given progressive concentrations of these chemicals in feed, to effects observed from progressive concentrations of the same chemicals in the aqueous living environment.

Despite nearly two decades of commercial cultivation and use, environmental impact of and health risk assessment of transgenic plants is a contested issue [19]-[21]. Also the interpretation of published evidence for risk assessment is contested [22]. It is thus appropriate to discuss how initial studies by chemical industry and biotech industry found transgenic RR-soybean as nutritious and safe as conventional soybean varieties. Compositional analyses of RR-soybean [23] led to the conclusion that the composition was essentially similar (substantially equivalent) to unmodified soy. Feeding studies [24] gave no indications of negative health impacts on rat, chicken, catfish or cattle. However, subsequent reviews by independent scientists highlighted that these initial studies were conducted with soybean material produced under non-representative agricultural conditions, since the tested Roundup-Ready-soy was not exposed to Roundup in the field [25]. Following feeding studies with RR-soybean were performed in swine [26] and mouse [27]. In addition, several composition studies assessing substantial equivalence of nutrient profiles [28] [29] were conducted. It was reported that the plants used in these studies had been exposed to the prescribed amounts of Roundup. Regrettably, measurement of residue levels was not provided in these studies. Recently Viljoen [30] reported that evidence in risk-assessment of RRcrops is still based on analysis of biological material which has not been subjected to application of glyphosate and thus can not be accepted as relevant safety assurance representative for the material actually entering feed production and human food. 
M. Cuhra et al.
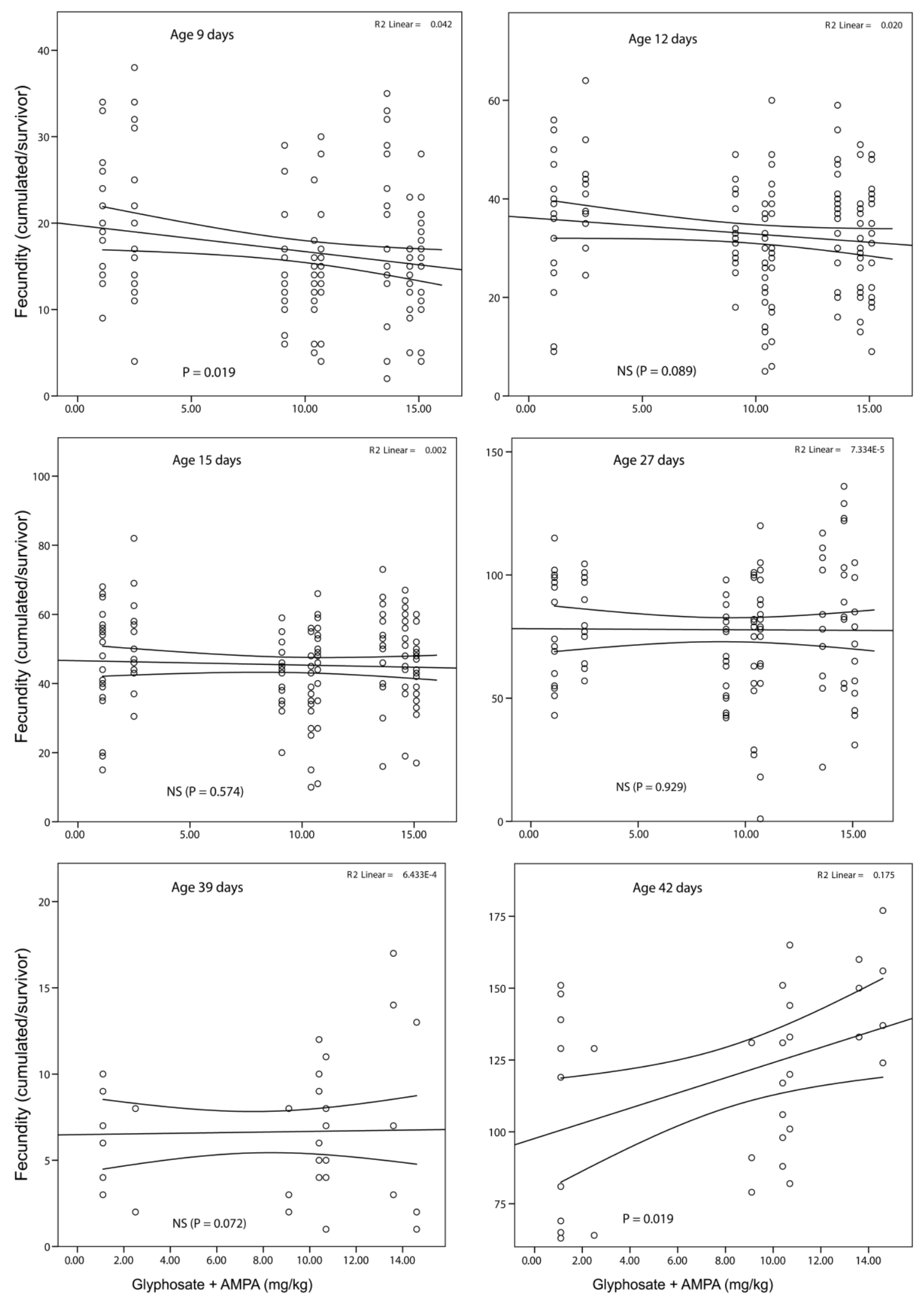

Figure 5. Fecundity (cumulated live births) of surviving D. magna fed experimental diets with varying levels of glyphosate residues, at ages 9, 12, 15, 27, 39 and 42 days (Error bands: 95\% CI). 
Independent researchers attempting to replicate industry studies have experienced various difficulties, mainly represented by prohibitive formalities enforced through patent laws and intellectual property rights which limit access to research materials [31]. Despite such difficulties, several independent researchers have obtained transgenic plant material, such as RR-soybean, and assessed its quality in compositional studies and animal feeding trials. Mice fed RR-soybean demonstrated significant morphological changes in liver cells [32]. The data suggested that RR-soybean intake was influencing liver cell nuclear features in both young and adult mice, but the mechanisms responsible for the alterations could not be identified by the experimental design of these studies. Malatesta and co-workers showed that mice fed RR-soybean developed altered mitochondrial functions and transcription pathways in hepatocytes [32] [33] and confirmed similar responses in hepatome-derived cell cultures by exposing them to low concentrations of Roundup [34]. Even without measurements of the herbicide residues levels, this work indicates that Roundup may have adverse toxicological effects. Zhu et al. [35] compared nutritional qualities of meal from conventional and RR-soybean in a 13-week sub-chronic rat feeding experiment with high inclusion rates (up to 90\% soy). Despite initial significant reduced feed intake and growth in the RR-soybean group (during the first week of experiment), no subsequent significant differences in feed intake, body weight nor mortality was seen. Neither post mortem histology nor haematological and urinary analyses showed significant effects attributable to feed type.

As RR-soybean now accounts for the majority of globally produced soybean, concern has been raised in relation to its increasing use in aquaculture feed. Several studies have tested effects of soybean as ingredients in aquaculture feed formulations. Sagstad et al. [13] compared organ development, metabolic markers and general health indicators of Atlantic salmon fed diets with RR-soybean to fish fed non-modified soy of a near-isogenic parental line. The results showed significant differences in investigated end-points between groups. Fish having been fed RR-soybean diets had significantly increased feed conversion ratios, significantly decreased protein efficiency ratio, significantly decreased apparent digestibility-coefficients of lipids and dry matter, and significantly decreased plasma triacylglycerol levels. These indications of functional and metabolic changes in fish liver, spleen and intestines were attributable to soy type (RR-soy versus unmodified isoline) and thus could be related to possible residues of glyphosate herbicide or other characteristics of RR-soybean. Later investigations provided new data that were inconclusive [36]. However, neither presence nor quantity of glyphosate residues was investigated. Bakke-Mckellep et al. [37] detected somewhat higher kidney lysozyme and acid phosphatase levels in Atlantic salmon after feeding RR-soybeans, but were not able to conclude whether this was caused by the genetic modification or other factors representing soy-cultivar difference. The authors did not mention herbicide residue levels. Other long-term feeding studies in Atlantic salmon have shown minor differences between RR-soybean and a near-isogenic conventional soybean, but not related to the genetic modification per se [38] [39]. Both these studies used soy material supplied by biotech industry and content of glyphosate residues were not analyzed. Previous experimental protocols for testing transgenic (GM) food and feed in D. magna [40] [41] have been criticized for 1) high inclusion rates of plant material [42] [43] and 2) longer duration than standard OECD D. magna 21-day reproduction testing [42]. These are important aspects to discuss. EFSA guidelines for animal feeding studies in nutritional and safety assessment of GM plants and derived feed specify that; "When testing whole foods, it is desirable to obtain the highest concentration possible of the GM food and feed in laboratory animal diet without causing nutritional imbalance” [44]. Thus, in order to investigate potential quality differences in the soybean meal, the present study was designed with multiple treatment groups, to combine the rationale for obtaining the highest possible concentration of the feed under testing, while keeping a balanced nutritional composition (i.e. standard green algae diet in addition to soy). We chose to use experimental diets consisting of $80 \%$ biomass (organic carbon) from soymeal and $20 \%$ biomass from unicellular green algae. The study is thus not representative of what consumer organisms would receive from commercially produced feed. Normal inclusion rates for soybean-meal are 15\% - 40\% in terrestrial farm animal feed [45] and 20\% - 30\% in aquaculture feed for species such as salmon and omnivorous fish [46] [47]. However, experimental protocols have been developed and validated for non-target organisms like D. magna for testing plant quality as food over the full life-cycle with $100 \%$ of the diet being the tested material [42] [43]. Herbivore species that live in proximity to monoculture fields will be exposed to large quantities/a high proportion of that crop, both in the terrestrial and in the soil ecosystem. Most testing protocols for non-target organisms feeding on transgenic material use $100 \%$ of the relevant material for testing (see e.g. reviews [48] [49]). Also in the aquatic run-off system, where other non-target biodiversity is found, including Daphnia spp., close to $100 \%$ of the incoming (allochthonous) plant material may come from crop residuals, debris and by-products [50]. Furthermore, most published 
feeding studies represent short-term exposure, compared to the life expectancy of the test organisms. However, the intended use of plant ingredients in food and feed for animals, including humans, impose lifetime chronic exposure for the consumer organism. Life-long feeding studies are time-consuming, expensive and hence rare. The first life-long study of a genetically modified plant and its co-technology herbicide in a rodent species tested the cp4 epsps-transgenic NK 603 maize (RR-maize) and Roundup during two years of continuous feeding in rats ([51], retracted and republished). The study indicated that rats fed RR-maize (with and without the application of Roundup), or given Roundup separately in the drinking water, developed problems in detoxification organs and developed significantly changed blood parameters. The retracted study by Seralini et al. highlights the role and relevance of life-cycle studies for herbicide tolerant GM crops, despite high costs. This has also been recognized by the European Commission and EFSA that agree to the need for two-year GMO feeding studies [52]. Our study in $D$. magna also represents a life-cycle study, but lasting 42 days only and with much lower costs than a two-year study in mammals. Although vertebrates have numerous responses that are unique to those organisms, e.g. due to their immune systems, we argue that many qualitative aspects of toxicity and nutrition can be tested with valuable information obtained in D. magna or similar invertebrate model organisms with relatively short life span and short generation times.

The revised EFSA guidelines for animal feeding studies in risk assessments also specify that it is not enough to only assess the added qualities stemming from expression of the inserted gene in a GM-plant, but also investigate possible effects of the genetic modification itself [53]. We argue that feeding studies with herbicide tolerant genetically modified plants also have to deal with and, ideally, should have the ability to differentiate effects stemming from the plant and those derived from the herbicides. Due to increasing occurrence of glyphosate-resistant weeds in agricultural systems, particularly in fields of glyphosate tolerant RR-crops [20], functionality of cultivars such as GTS 40-3-2 RR-soybean has decreased. To combat resistant weeds new varieties of genetically modified soybeans are developed in order to 1 ) have higher tolerance to herbicides such as glyphosate and 2) be tolerant to additional active herbicide ingredients such as glufosinate-ammonium, dicamba and 2,4-D [54]. Even glyphosate resistant weeds can be eradicated with glyphosate (Roundup) alone, if the dosage is sufficiently high. New varieties of glyphosate-tolerant soybean, such as MON 89788 are designed to provide tolerance to higher doses than first-generation GTS 40-3-2 soybean and may thus allow for intensive eradication of semi-resistant weeds. This may lead to increased application rates and thus also increased residue levels in the end products. To our knowledge, no previous feeding studies have addressed and tested dose-response relationship in plant samples with different amounts of pesticide residues. This becomes more and more relevant as the regulatory systems allow progressively higher maximum residue levels of glyphosate and other herbicides present in biomass produced from herbicide-tolerant crops.

\section{Materials and Methods}

\subsection{Materials}

The tested soybeans were grown on a number of agricultural farm fields in the State of Iowa, USA. All samples were from agriculture of glyphosate tolerant (Roundup-Ready) soybean. Soy material for testing was obtained from bags of $3 \mathrm{~kg}$ samples of whole beans, representing harvests from 8 individual fields. Seed type, farming history including pesticide use and nutritional composition was known for all samples [2]. All fields were treated with normal application rates of either Roundup glyphosate herbicide (Monsanto) or Touchdown glyphosate herbicide (Syngenta). D. magna mother-populations were reared for several generations in fully synthetic Elendt M7 artificial lake water [55] fed diets of Selenastrum sp. unicellular algae. Test animals consisted of juvenile $D$. magna less than 24 hrs old, taken from mother population 3 - 5 clutch.

\subsection{Methods}

The feeding experiment setup included 8 individual feed-types, with 20 animals in each feeding group, plus an integrated control group fed only algae. Soy feed was given in a Daphnia magna long-term reproduction study for a duration of 42 days, which covers the full life-cycle of the animal (life expectancy is $30-45$ days). The experiment was conducted in the laboratories of GenØk-Centre for Biosafety, Tromsø, Norway. Upon arrival in the laboratory, soybean samples were cleaned manually, i.e. impurities and other plant material were removed. Standardized subsamples for analysis and feeding tests were prepared by homogenization after weighing and 
grinding. Material was kept cool during grinding, to avoid degradation of essential components. Ground soy samples were analyzed for pesticide residues at Eurofins laboratories GfA, Otto-Hahn-Str. 22, D-48161 Münster (Germany). Details on soy-meal composition including multivariate analyses are presented in Bøhn et al., 2014. The raw feed from Roundup Ready GM soy contained both glyphosate and the degradation product aminomethylphosphonic acid (AMPA) (Figure 1). Soy diets for the main experiments were produced from finely ground and dried soy-bean meal, homogenized and subsequently filtered through $200 \mu \mathrm{m}$ Retsch metal filters. Subsamples of $0.800 \mathrm{~g}( \pm 0.5 \mathrm{mg})$ were taken from each category, each homogenized into $1000 \mathrm{ml}$ ultraclean screw-cork flasks containing $200.0 \mathrm{ml}$ of ultrapure water by manual shaking for 60 seconds, settling and subsequent 5 minute shaking. Flasks with the feed solutions were blinded, and individual $8 \mathrm{ml}$ aliquots were prepared for freezing in colour-coded $14 \mathrm{ml}$ PP tubes (Falcon). Feed was kept frozen at $-18 \mathrm{C}$ until use. Daily feeding dose of $100 \mu \mathrm{l}$ containing $0.2 \mathrm{mg}$ organic carbon soy biomass ( $80 \%$ of feed), was precisely administered using micropipette combined with supplementary $0.05 \mathrm{mg}$ C/d as Selenastrum sp. algal feed in all diets ( $20 \%$ of feed). 160 juvenile D. magna test animals were reared and kept as individual experimental units in $100 \mathrm{ml}$ glasses for the duration of the experiment. 13 animals fed only standard laboratory diets of $0.15 \mathrm{mg}$ C/d as Selenastrum algae feed were integrated as control. At day 21 of the experimental period, average fecundity of the 12 surviving individuals in this control was 79 ( $\mathrm{SE}=5$ ). Holding medium for experiment was Elendt-M7 artificial lake water [55]. Physical parameters temperature, dissolved oxygen, conductivity and $\mathrm{pH}$ were measured regularly. The feed identity was blinded in the experiment and allocation of animals to feed treatment and position of experimental units on lab bench were randomized. Experimental setup was on 6 trays each having 6 treatments with 5 experimental units consisting of colour coded and numbered individual glasses of each treatment, in laboratory environment. Feeding and registration of mortality, reproductive maturity and fecundity endpoints were performed on a daily basis for the 42-day duration of the experiment. Juveniles were quantified and removed every 3 days. On days 12, 21, 30 and 42 all surviving animals were photographed through a Leitz fixed magnification loupe fitted with a Nikon D300 high-resolution digital camera, for subsequent measurement of carapace length (anterior extreme of head-shield to base of caudal spine) according to standardized procedure using Wayne-Rasband Image-J software [56] [57] calibrated to an Agar-L4078 scale. The holding-medium was renewed every 3d day. Experimental units were randomly re-positioned following medium renewal. Survival, growth, age at maturation, fecundity and abortion rate, were compared across treatments and correlated to feed characteristic pesticide content, defined as total glyphosate residue levels calculated on the basis of analytic results for glyphosate + aminomethylphosphonic acid (AMPA). The performance of the control group (exclusively fed algae diet) validated overall quality of experimental conditions. Collected data were analyzed with the SPSS and R statistical softwares. Mortality of individual animals in different feeding groups was analyzed by Cox Proportional Hazard (Cox-PH-test). The main measured outcomes with respect to growth, age at maturity and fecundity (number of living young as well as abortions) were analyzed in relation to magnitude of glyphosate residues by Pearson correlation analysis.

\section{Conclusion}

Published studies for regulatory assessment of herbicide tolerant crops largely lack information on herbicide residue presence. This is a serious shortcoming on a key factor that may impair the quality of such crops. We show that glyphosate residues in "ready to market" RR-soybean affected D. magna life-history traits negatively in a dose-response model. This indicates that "normally occurring levels" of glyphosate residues in soy-meal feed can have negative biological effects. The investigated residue levels are well within current MRLs of $40 \mathrm{mg} / \mathrm{kg}$ for soybean in USA. The tested RR-soybean material was harvested from commercial farm fields and is representative of the soybean biomass which is dominantly used for feed purposes world-wide. Our results warrant further research related to potential health consequences in consumer organisms. Pesticide residues in food and feed produced from herbicide-tolerant plants needs to be routinely monitored and we urge for further testing of potential effects on farmed animals at realistic chronic exposure rates. Finally, we recommend revisions of guidelines for risk-assessment of genetically modified herbicide tolerant cultivars and for animal feeding-trials to specifically address herbicide residues in food and feed.

\section{References}

[1] USDA (2013) United States Department of Agriculture. Foreign Agricultural Service, Table 07: Soybeans: World 
Supply and Distribution. (Online Statistics) www.fas.usda.gov/psdonline

[2] Bøhn, T., et al. (2014) Compositional Differences in Soybeans on the Market: Glyphosate Accumulates in Roundup Ready GM Soybeans. Food Chemistry, 153, 207-215. http://dx.doi.org/10.1016/j.foodchem.2013.12.054

[3] Cuhra, M., Traavik, T. and Bøhn, T. (2014) Growth and Fecundity of Crustacean D. magna in Life-Cycle Feeding with Roundup Ready, Conventional or Organic Soybean (accepted 7. March 2014: Aquaculture Nutrition).

[4] Cuhra, M., Traavik, T. and Bøhn, T. (2013) Clone- and Age-Dependent Toxicity of a Glyphosate Commercial Formulation and Its Active Ingredient in Daphnia magna. Ecotocicology, 22, 251-262.

http://dx.doi.org/10.1007/s10646-012-1021-1

[5] Amrhein, N., Schab, J. and Steinrücken, H.C. (1980) The Mode of Action of the Herbicide Glyphosate. Naturwissenschaften, 67, 356-357. http://dx.doi.org/10.1007/BF01106593

[6] Duke, S.O., Rimando, A., Pace, P.F., Reddy, K.N. and Smeda, R.J. (2003) Isoflavone, Glyphosate, and Aminomethylphosphonic Acid Levels in Seeds of Glyphosate-Treated, Glyphosate-Resistant Soybean. Journal of Agricultural and Food Chemistry, 51, 340-344. http://dx.doi.org/10.1021/jf025908i

[7] Arregui, M.C., et al. (2004) Monitoring Glyphosate Residues in Transgenic Glyphosate-Resistant Soybean. Pest Management Science, 60, 163-166. http://dx.doi.org/10.1002/ps.775

[8] Then, C. (2013) High Levels of Residues from Spraying with Glyphosate Found in Soybeans in Argentina. Testbiotech Institute for Independent Impact Assessment in Biotechnology Report. http://www.testbiotech.de/en/node/926

[9] Zobiole, L.H.S., et al. (2010) Effect of Glyphosate on Symbiotic $\mathrm{N}_{2}$ Fixation and Nickel Concentration in Glyphosate-Resistant Soybeans. Applied Soil Ecology, 44, 176-180. http://dx.doi.org/10.1016/j.apsoil.2009.12.003

[10] Zobiole, L.H.S., et al. (2010) Glyphosate Affects Seed Composition in Glyphosate-Resistant Soybean. Journal of Agricultural and Food Chemistry, 58, 4517-4522. http://dx.doi.org/10.1021/jf904342t

[11] Zobiole, L.H.S., Kremer, R.J., Oliveira Jr., R.S. and Constantin, J. (2011) Glyphosate Affects Chlorophyll, Nodulation and Nutrient Accumulateion of "Second Generation" Glyphosate-Resistant Soybean (Glycine max L.). Pesticide Biochemistry and Physiology, 99, 53-60. http://dx.doi.org/10.1016/j.pestbp.2010.10.005

[12] Gillund, F. and Myhr, A.I. (2010) Perspectives on Salmon Feed: A Deliberative Assessment of Several Alternative Feed Resources. Journal of Agricultural and Environmental Ethics, 23, 527-550. http://dx.doi.org/10.1007/s10806-010-9237-7

[13] Sagstad, A., Sanden, M., Krogdahl, Å., Bakke-McKellep, A.M., Frøystad, M. and Hemre, G.-I. (2008) Organs Development, Gene Expression and Health of Atlantic Salmon (Salmo salar L.) Fed Genetically Modified Soybeans Compared to the Near-Isogenic Non-Modified Parental Line. Aquaculture Nutrition, 14, 556-572. http://dx.doi.org/10.1111/j.1365-2095.2008.00630.x

[14] Refstie, S., Korsøen, Ø.J., Storebakken, T., Baeverfjord, G., Lein, I., et al. (2000) Differing Nutritional Response to Dietary Soybean Meal in Rainbow Trout (Oncorhynchus mykiss) and Atlantic Salmon (Salmo salar). Aquaculture, 190, 49-63. http://dx.doi.org/10.1016/S0044-8486(00)00382-3

[15] Yang, Y., Wang, Y., Lu, Y. and Li, Q.-Z. (2011) Effect of Replacing Fish Meal with Soybean Meal on Growth, Feed Utilization and Nitrogen and Phosphorus Excretion on Rainbow Trout (Oncorhynchus mykiss). Aquaculture International, 19, 405-419. http://dx.doi.org/10.1007/s10499-010-9359-y

[16] Cuzon, G., Guillaume, J. and Cahu, C. (1994) Composition, Preparation and Utilization of Feeds for Crustacea. Aquaculture, 124, 253-267. http://dx.doi.org/10.1016/0044-8486(94)90387-5

[17] Jones, P.L. and De Silva, S.S. (1997) Apparent Nutrient Digestibility of Formulated Diets by the Australian Freshwater Crayfish Cherax destructor Clark (Decapoda, Parastacidae). Aquaculture Research, 28, 881-891.

[18] Kumaraguru Vasagam, K.P., Ramesh, S. and Balasubramanian, T. (2005) Dietary Value of Different Vegetable Oil in Black Tiger Shrimp Penaeus monodon in the Presence and Absence of Soy Lecithin Supplementation: Effect on Growth, Nutrient Digestibility and Body Composition. Aquaculture, 250, 317-327. http://dx.doi.org/10.1016/j.aquaculture.2005.02.035

[19] Antoniou, M., Robinson, C. and Fagan, J. (2012) Teratogenic Effects of Glyphosate-Based Herbicides: Divergence of Regulatory Decisions from Scientific Evidence. Journal of Environmental and Analytical Toxicology, 4, 006.

[20] Benbrook, C.M. (2012) Impacts of Genetically Engineered Crops on Pesticide Use in the U.S.-The First Sixteen Years. Environmental Science Europe, 24, 24. http://dx.doi.org/10.1186/2190-4715-24-24

[21] Jennings, R.C. (2013) Social and Ethical Issues Raised by NGOs and How They Can Be Understood. In: Bennet, D.J. and Jennings, R.C., Eds., Successful Agricultural Innovation in Emerging Economies, Cambridge University Press, Cambridge, 386-399. http://dx.doi.org/10.1017/CBO9781139208475.028 
[22] Wickson, F., Bøhn, T., Wynne, B., Hilbeck, A. and Funtowicz, S. (2013) Science-Based Risk Assessment Requires Careful Evaluation of All Studies. Nature Biotechnology, 31, 1077-1078. http://dx.doi.org/10.1038/nbt.2761

[23] Padgette, S.R., Taylor, N.B., Nida, D.L., Bailey, M.R., MacDonald, J., Holden, L.R. and Fuchs, R.L. (1996) The Composition of Glyphosate-Tolerant Soybeans Is Equivalent to That of Conventional Soybeans. Journal of Nutrition, 126, 702-716.

[24] Hammond, B.G., Vicini, J.L., Hartnell, G.F., Naylor, M.W., Knight, C.D., Robinson, E.H., et al. (1996) The Feeding Value of Soybeans Fed to Rats, Chickens, Catfish and Dairy Cattle Is Not Altered by Incorporation of Glyphosate Tolerance. Journal of Nutrition, 126, 717-727.

[25] Millstone, E., Brunner, E. and Mayer, S. (1999) Beyond Substantial Equivalence. Nature, 401, 525-526. http://dx.doi.org/10.1038/44006

[26] Cromwell, G.L., Lindemann, M.D., Randolph, J.H., Parker, G.R., Coffey, R.D., Laurent, K.M., et al. (2002) Soybean Meal from Roundup Ready or Conventional Soybeans in Diets for Growing-Finishing Swine. Journal of Animal Science, 80, 708-715.

[27] Brake, D.G. and Evenson, D.P. (2004) A Generational Study of Glyphosate-Tolerant Soybeans on Mouse Fetal, Postnatal, Pubertal and Adult Testicular Development. Food and Chemical Toxicology, 42, 29-36. http://dx.doi.org/10.1016/j.fct.2003.08.003

[28] Harrigan, G.G., Ridley, W.P., Riordan, S.G., Nemeth, M.A., Sorbet, R., Trujillo, W.A., et al. (2007) Chemical Composition of Glyphosate-Tolerant Soybean 40-3-2 Grown in Europe Remains Equivalent with That of Conventional Soybean (Glycine max L.). Journal of Agricultural and Food Chemistry, 55, 6160-6168. http://dx.doi.org/10.1021/jf0704920

[29] Lundry, D.R., Ridley, W.P., Meyer, J.J., Riordan, S.G., Nemeth, M.A., et al. (2008) Composition of Grain, Forage, and Processed Fractions from Second-Generation Glyphosate-Tolerant Soybean, MON 89788 Is Equivalent to That of Conventional Soybean (Glycine max L.). Journal of Agricultural and Food Chemistry, 56, 4611-4622. http://dx.doi.org/10.1021/jf073087h

[30] Viljoen, C. (2013) Letter to the Editor. Food and Chemical Toxicology, 59, 809-810. http://dx.doi.org/10.1016/j.fct.2013.07.003

[31] Nielsen, K.M. (2013) Biosafety Data as Confidential Business Information. PLoS Biology, 11, e1001499. http://dx.doi.org/10.1371/journal.pbio.1001499

[32] Malatesta, M., Caporaloni, C., Gavaudan, S., Rocchi, M.B.L., Serafini, S., Tiberi, C., et al. (2002) Ultrastructural Morphometrical and Immunecytochemical Analysis of Hepatocyte Nuclei from Mice Fed on Genetically Modified Soy Bean. Cell Structure and Function, 27, 173-180. http://dx.doi.org/10.1247/csf.27.173

[33] Malatesta, M., Boraldi, F., Annovi, G., Baldelli, B., Battistelli, S., Biggiogera, M., et al. (2008b) A Long-Term Study on Female Mice Fed on a Genetically Modified Soybean: Effects on Liver Ageing. Histochemistry and Cell Biology, 130, 967-977. http://dx.doi.org/10.1007/s00418-008-0476-X

[34] Malatesta, M., Perdoni, F., Santin, G., Battistelli, S., Muller, S., Biggioger, M., et al. (2008a) Hepatoma Tissue Culture (HTC) Cells as a Model for Investigating the Effects of Low Concentrations of Herbicide on Cell Structure and Function. Toxicology in Vitro, 22, 1853-1860. http://dx.doi.org/10.1016/j.tiv.2008.09.006

[35] Zhu, Y., Li, D., Wang, F., Yin, J. and Jin, H. (2004) Nutritional Assessment and Fate of Dna of Soybean Meal from Roundup Ready or Conventional Soybeans Using Rats. Archives of Animal Nutrition, 58, 295-310. http://dx.doi.org/10.1080/00039420412331273277

[36] Sissener, N.H., Sanden, M., Krogdahl, Å., Bakke, A.-M., Johannessen, L.E. and Hemre, G.-I. (2011) Genetically Modified Plants as Fish Feed Ingredients. Canadian Journal of Fisheries and Aquatic Sciences, 68, 563-574. http://dx.doi.org/10.1139/F10-154

[37] Bakke-McKellep, A.M., Koppang, E.O., Gunnes, G., Sanden, M., Hemre, G-I., Landsverk, T. and Krogdahl, Å. (2007) Histological, Digestive, Metabolic, Hormonal and Some Immune Factor Responses in Atlantic Salmon, Salmo salar L., Fed Genetically Modified Soybeans. Journal of Fish Diseases, 30, 65-79. http://dx.doi.org/10.1111/j.1365-2761.2007.00782.x

[38] Sissener, N.H., Bakke, A.M., Gu, J., Penn, M.H., Eie, E., Krogdahl, Å., et al. (2009) An Assessment of Organ and Intestinal Histomorphology and Cellular Stress Response in Atlantic Salmon (Salmo salar L.) Fed Genetically Modified Roundup Ready ${ }^{\circledR}$ Soy. Aquaculture, 298, 101-110. http://dx.doi.org/10.1016/j.aquaculture.2009.10.011

[39] Sissener, N.H., Sanden, M., Bakke, A.M., Krogdahl, A. and Hemre, G.I. (2009) A Long Term Trial with Atlantic Salmon (Salmo salar L.) Fed Genetically Modified Soy; Focusing General Health and Performance Before, during and after the Parr-Smolt Transformation. Aquaculture, 294, 108-117. http://dx.doi.org/10.1016/j.aquaculture.2009.05.002

[40] Bøhn, T., Primicerio, R., Hessen, D.O. and Traavik, T. (2008) Reduced Fitness of Daphnia magna Fed a Bt-Transgenic Maize Variety. Archives of Environmental Contamination and Toxicology, 55, 584-592. http://dx.doi.org/10.1007/s00244-008-9150-5 
[41] Bøhn, T., Traavik, T. and Primicerio, R. (2010) Demographic Responses of Daphnia magna Fed Transgenic Bt-Maize. Ecotoxicology, 19, 419-430. http://dx.doi.org/10.1007/s10646-009-0427-x

[42] EFSA (2009) Scientific Opinion on Applications for Renewal of Authorization for the Continued Marketing of Maize MON 81 and Existing Derived Food and Feed Products. EFSA Journal, 1149, 38-85.

[43] Ricroch, A., Bergé, J.B. and Kuntz, M. (2010) Is the German Suspension of MON810 Maize Cultivation Scientifically Justified? Transgenic Research, 19, 1-12. http://dx.doi.org/10.1007/s11248-009-9297-5

[44] EFSA (2008) Safety and Nutritional Assessment of GM Plants and Derived Food and Feed: The Role of Animal Feeding Trials. Food and Chemical Toxicology, 46, S1-S70. http://dx.doi.org/10.1016/j.fct.2008.02.013

[45] OECD (2001) Consensus Document on Compositional Considerations for New Varieties of Soybean: Key Food and Feed Nutrients and Antinutrients. OECD Environmental Health and Safety Publications Series on the Safety of Novel Foods and Feeds, No. 2. Environment Directorate, Organization for Economic Co-Operation and Development, Paris.

[46] Ellingsen, H., Olaussen, J.O. and Utne, I.B. (2009) Environmental Analysis of the Norwegian Fishery and Aquaculture Industry-A Preliminary Study Focusing on Farmed Salmon. Marine Policy, 33, 479-488. http://dx.doi.org/10.1016/j.marpol.2008.11.003

[47] Olsen, R.L. and Hasan, M.R. (2012) A Limited Supply of Fishmeal: Impact on Future Increases in Global Aquaculture Production. Trends in Food Science \& Technology, 27, 120-128.

[48] Lövei, G.L. and Arpaia, S. (2005) The Impact of Transgenic Plants on Natural Enemies: A Critical Review of Laboratory Studies. Entomologia Experimentalis et Applicata, 114, 1-14.

[49] Lövei, G.L., Andow, D.A. and Arpaia, S. (2009) Transgenic Insecticidal Crops and Natural Enemies: A Detailed Review of Laboratory Studies. Environmental Entomology, 38, 293-306. http://dx.doi.org/10.1603/022.038.0201

[50] Rosi-Marshall, E.J., Tank, J.L., Royer, T.V., Whiles, M.R., Evans-White, M., Chambers, C., et al. (2007) Toxins in Transgenic Crop Byproducts May Affect Headwater Stream Ecosystems. Proceedings of the National Academy of Sciences of the United States of America, 104, 16204-16208. http://dx.doi.org/10.1073/pnas.0707177104

[51] Séralini, G.E., Clair, E., Mesnage, R., Gress, S., Defarge, N., Malatesta, M., et al. (2014) Long Term Toxicity of a Roundup Herbicide and a Roundup-Tolerant Genetically Modified Maize. Environmental Sciences Europe, 26, 14.

[52] EFSA (2013) Considerations on the Applicability of OECD TG 453 to Whole Food/Feed Testing. EFSA Journal, 11, 3347.

[53] EFSA (2010) Guidance on the Environmental Risk Assessment of Genetically Modified Plants. EFSA Journal, 8, 1111.

[54] ISAAA (2014) GM Approval Database. International Service for the Acquisition of Agri-Biotech Applications (ISAAA). http://www.isaaa.org/gmapprovaldatabase/

[55] OECD (2008) OECD-211 Guidelines for Testing of Chemicals: Daphnia magna Reproduction Test. OECD, Geneva.

[56] Collins, T. (2007) ImageJ for Microscopy. BioTechniques, 43, S25-S30. http://dx.doi.org/10.2144/000112517

[57] Dorr, R., Ozu, M. and Parisi, M. (2007) Simple and Inexpensive Hardware and Software Method to Measure Volume Changes in Xenopus Oocytes Expressing Aquaporins. Journal of Neuroscience Methods, 161, 301-305. http://dx.doi.org/10.1016/j.jneumeth.2006.11.005 


\section{Supporting Information}

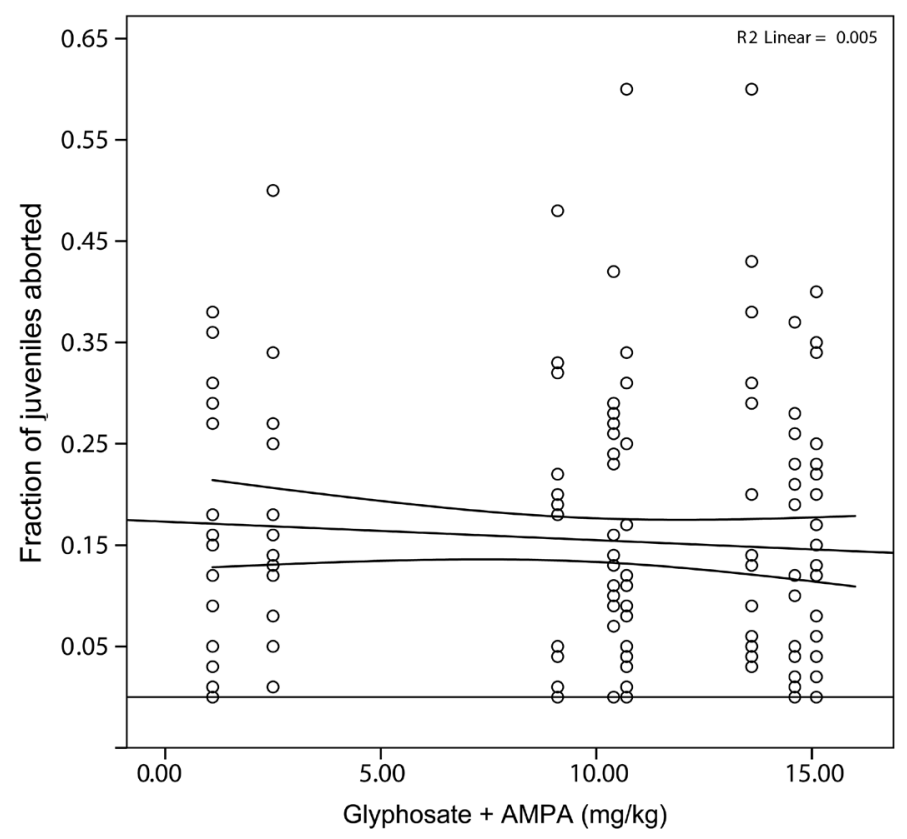

Figure S1. Abortion rates for each individual D. magna, related to level of glyphosate residues in feed (Error bands: 95\% CI).

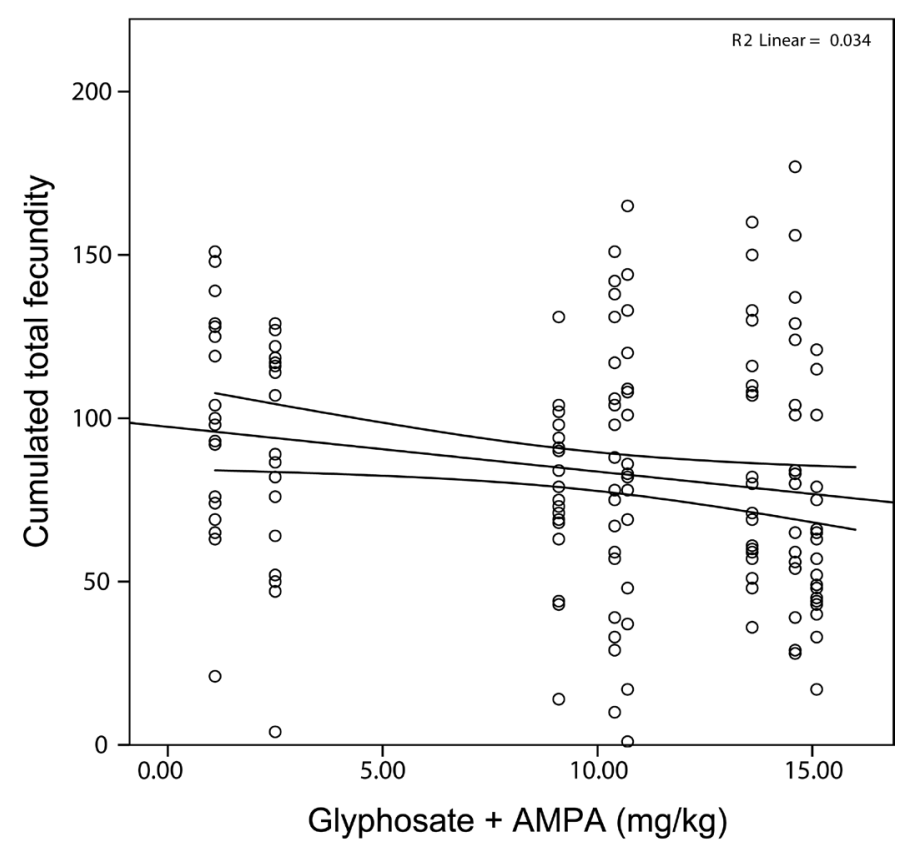

Figure S2. Total D. magna fecundity (cumulated live births) related to levels of glyphosate residues (Error bands: 95\% CI). 
Scientific Research Publishing (SCIRP) is one of the largest Open Access journal publishers. It is currently publishing more than 200 open access, online, peer-reviewed journals covering a wide range of academic disciplines. SCIRP serves the worldwide academic communities and contributes to the progress and application of science with its publication.

Other selected journals from SCIRP are listed as below. Submit your manuscript to us via either submit@scirp.org or Online Submission Portal.
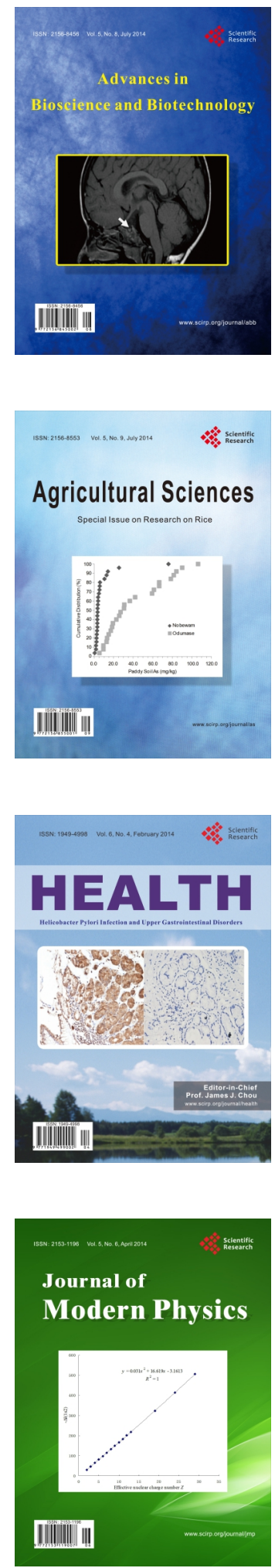
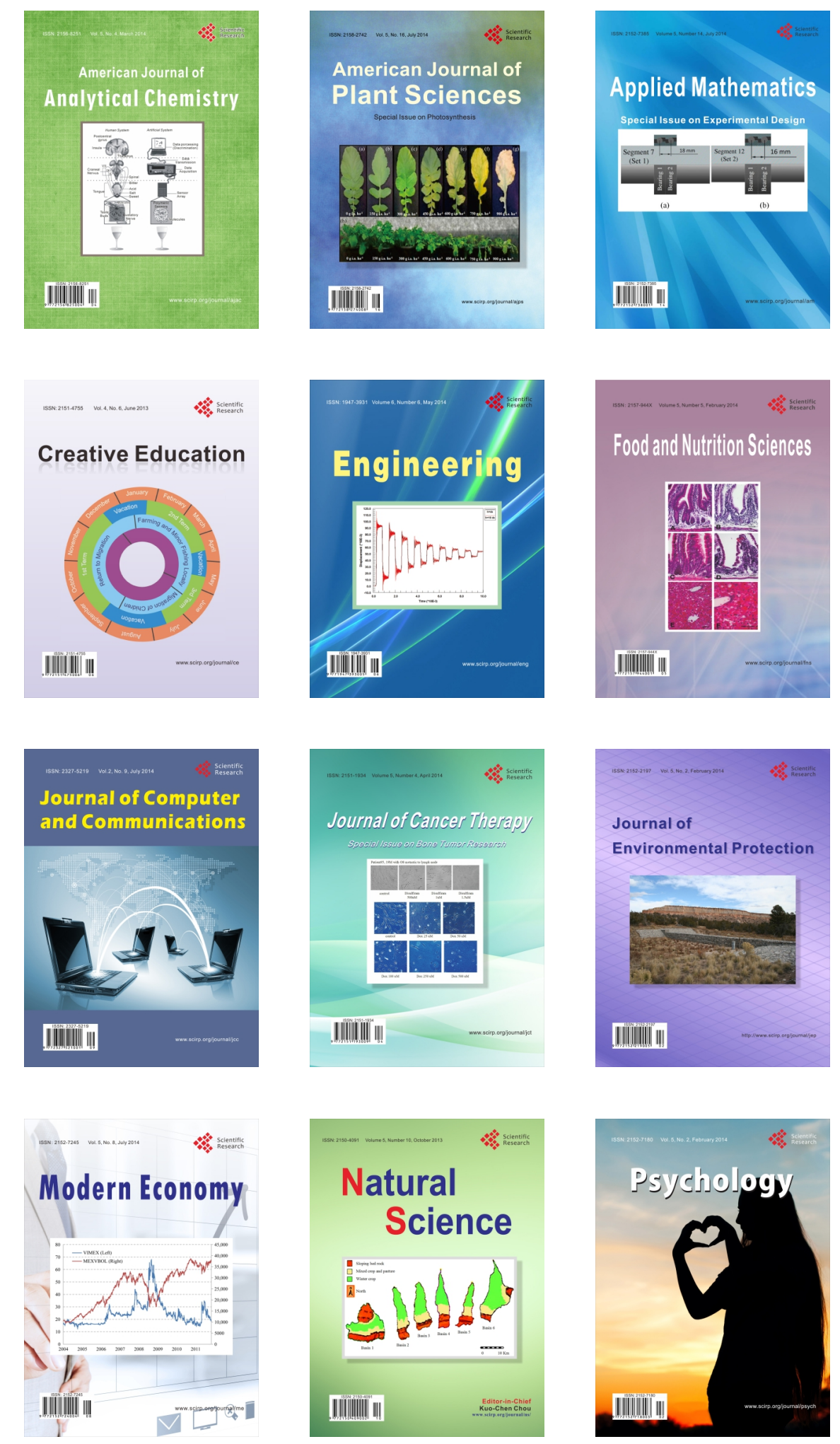